\title{
Heavy metal resistant clones of willows from polluted areas useful for land restoration programmes
}

Friedrich W.C. Mang

Am Knill 24, D-2000 Hamburg 73, Germany

and

Rainer Reher

Grüner Weg 1, D-2057 Büchen, Germany

In order to keep the tidal port of Hamburg navigable for big ships, silt is constantly removed and dried in special landfills, the so-called 'Spülfelder'. These silt deposit areas in the port region afford the most heavily polluted substrates in this region, since the silt absorbs the industrial pollutants from both the upper Elbe and the Hamburg region, such as phenolics, halogenated carbohydrates and heavy metals. Apparently, the special conditions of these silt deposit areas act strongly selectively on germination and development of plants. Fresh silt provides, however, an ideal seed bed, and superficially dry silt deposits are quickly covered with a special flora. Among these, willows play an important role.

All willows found on these places belong to the Salix smithiana-dasyclados complex which stems from

Salix $\times$ smithiana Willd. (=S. caprea $\times$ viminalis $)$, and

Salix $\times$ dasyclados Wimm. $(=<\mathrm{S}$. $\times$ smithiana $>\times$ S. cinerea $)$.

Male and femal clones taken from this material have been tested in various programmes and have proven to be excellently suited for planting in polluted areas, such as silt deposits, roadside verges, railway dams; they also have proven to be resistant to moderate salinity.

\section{Restoration of montane willow scrub on Ben Lawers National Nature Reserve.}

\section{K. Mardon and H. M. Cole}

The National Trust for Scotland, Fagus, Manse Road, Killin, Perthshire FK21 9SH

Ben Lawers National Nature Reserve (NNR) is managed jointly by The National Trust for Scotland (NTS) and The Nature Conservancy Council for Scotland (NCCS). Recently, it has been recognised that isolated willow plants on the reserve represent the remnants of a montane scrub community which has declined throughout Scotland (Mardon 1990). Some of these species are now uncommon and severely restricted in range. Active conservation measures have been initiated to restore areas of montane willow scrub.

Grazing by sheep has been identified as one of the greatest threats to the surviving species. Recovery and regeneration can only begin if this is removed. Enclosure fences have, therefore, been erected to protect selected areas from grazing. Although these areas contain populations of willows, conditions are often not 